\title{
COMBINED HEAT AND POWER DISTRIBUTED GENERATION FOR HIGHER FUEL EFFICIENCY IN INDUSTRIAL PLANTS IN YEMEN
}

\author{
Omar H. Al-Sakaf \\ Department of Electrical Engineering, Faculty of Engineering \\ Sana'a University \\ E-mail: alsakafo@maktoob.com
}

(Received April 12, 2007 Accepted, June 6, 2007)

\begin{abstract}
Industry in Yemen is of small scale; most of industrial plants rely on themselves to meet their power needs, with apparently very low fuel efficiency. Combined heat and power generation, which is the simultaneous generation of heat and power using a single fuel such as natural gas, with overall fuel efficiencies of more than $80 \%$, is still not introduced and not known.

This paper aims at highlighting the possible technical, economical and environmental advantages of introducing combined heat and power units, and discusses barriers to their introduction. Finally, a practical approach to gradual combined heat and power introduction is proposed.
\end{abstract}

KEYWORDS: Combined Heat and Power Generation, Distributed Power Generation, Fuel Efficiency, Policy Framework, Gradual Introduction

\section{INTRODUCTION}

Industry in Yemen is of small scale, except the cement and oil extracting and refining industry, which is extending recently. Yemen depends to $100 \%$ on fossil fuels. Although considerable reserves of natural gas exist, petroleum products are the energy source for manufacturers. Industrial complexes depend on petroleum products to cover their energy needs and power is usually purchased from the very limited national grid. The public power supply system suffers from shortage in generation, high losses, frequent interruptions and poor power quality. This situation has forced in recent years many manufacturers to go off-grid and run own diesel generator sets. Public power supply is at the moment unable to satisfy the growing industrial consumers needs, both in terms of magnitude of demand and power quality.

Now, a lot of manufacturers have own diesel generators, working as prime and/or continuous duty generators. All generation capacity in the industrial sector is based on using small-scale internal combustion reciprocating engines, which have poor electrical efficiency ranging from $25 \%$ up to $35 \%$, as depicted in Figure (1) and Table (1), which show the typical energy balance in per cent $(\%)$ for reciprocating engines.

Many of industrial establishments, such as cement, food processing industries and refineries, cover their heat needs by means of boilers fired either by heavy fuel oil or diesel, which is wide spread. Small-scale diesel generator sets (under $1000 \mathrm{~kW}$ ) are 
typical in the majority of light industries, larger unit sizes, exceeding $1000 \mathrm{~kW}$ are used in food processing industries, cement industry and petrol extraction (up to 5-8 MW).

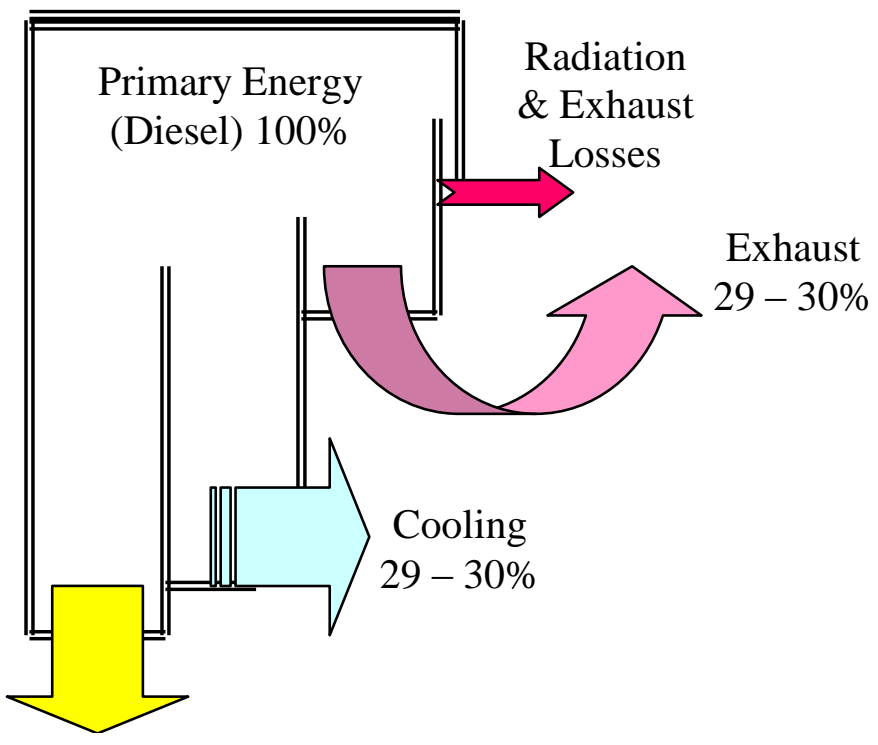

Electrical Energy

$33-35 \%$

Fig. (1): Energy Balance of a Diesel Engine Generator Set

Table (1): Typical Energy Distribution in Percent (\%) for Reciprocating Engines [1]

\begin{tabular}{lccc}
\hline \multicolumn{1}{c}{ Size in kW } & 60 & $230-840$ & $1200-2400$ \\
\hline Electric Output & 26 & 33 & 35 \\
\hline Cooling & 23 & 30 & 29 \\
\hline Exhaust & 47 & 30 & 29 \\
\hline $\begin{array}{l}\text { Losses (Heat Radiation and Exhaust } \\
\text { Losses) }\end{array}$ & 4 & 7 & 7 \\
\hline Total (Fuel Input) \% & 100 & 100 & 100 \\
\hline
\end{tabular}

The typical reachable overall fuel efficiencies for existing facilities, assuming a varying generator set efficiency (ranging from 30\% up to 35\%) and heat-to-power ratios varying from 1:1 to 10:1 (using both boiler techniques, classical/old: with efficiencies not exceeding $85 \%$ and modern designs that reach very high efficiencies up to $98 \%$ ) do not exceed $50 \%$, a clearly poor overall fuel efficiency achieved through separate production of heat and power that represents wasting energy with negative impacts on corporations economies and overall national economy. 


\section{WHAT ARE COMBINED HEAT AND POWER UNITS?}

Combined heat and power (CHP) units produce electricity (power) and heat simultaneously using a single fuel (such as natural gas), and are one of the distributed generation options for producing energy close to the user, with power ratings ranging from some kW's to some MW's. The waste heat produced from the electricity generating process is recovered and utilized to cover thermal loads (steam, water heating, cooling, desalination, ... etc.), hence they can be utilized at applications with high heat demand, such as hospitals, hotels and industrial sites with process heating and or cooling requirements. Basic components of CHP schemes, as described in [2], are shown diagrammatically in Figure (2) and discussed briefly underneath.

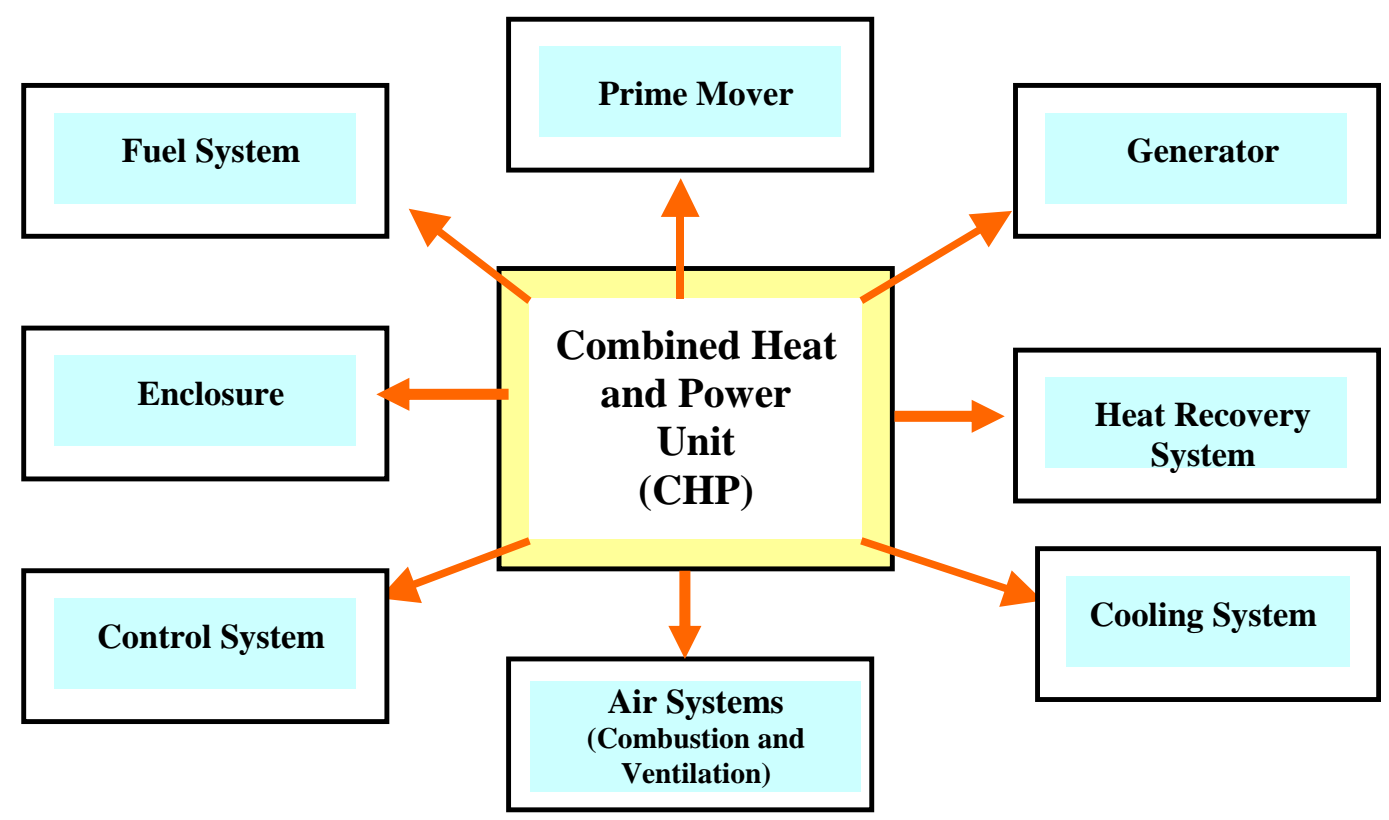

Fig. (2): Basic Components of CHP Schemes

- Either reciprocating engines or (micro) gas turbines can be used as prime movers for CHP units depending on the heat and power demand and the type of fuel available on site. Typical heat-to-power ratios amount to 1.5-2:1 (for reciprocating engines, attractive for food, paper industries, $50 \mathrm{kWe}-10 \mathrm{MWe}$ ) and 3-7:1 (for gas turbines, petroleum refining, chemical industries, $100 \mathrm{kWe}$, or even less 'micro turbines' $-200 \mathrm{MWe}$ ) [2].

- The function of the heat recovery system is to recover usable heat from the prime mover, the heat that is not converted to electrical output is rejected and may be recovered. Heat recovery, normally by heat exchangers to the appropriate service, is dependent on being able to match the required service and engine parameters [2].

- The cooling system is required to dissipate heat rejected from the engine that can not be recovered, for the following circumstances: 
- Oil and inter-cooled circuits where dedicated cooling radiators and fans may be used

- Jacket water cooling circuit at times when the heat demands are low and the heat must still be dissipated to prevent the engine from stopping on high coolant temperature

- A heat rejection matrix coil and fan in an outside location (or alternative system) may be used

- A control system to maintain safe and efficient operation of the CHP unit is concerned with [2]:

- Ensuring that the CHP engine runs safety and efficiently

- Integrating the heat produced with the heat demand system (thermal loads)

- Synchronizing, paralleling and disconnecting the generator safely (electrical loads)

- Monitoring the CHP plant for performance, maintenance and accounting purposes

- Prime movers used for CHP will always require some form of enclosure and mountings to provide protection from elements and attenuation of [2]:

o Air borne noise

o Structure-borne noise

o Exhaust and ventilation system noise

o Vibration from engine feet and pipe system

Containerized CHP units are also increasingly available with attractive designs enabling more flexibility and mobility for users.

- CHP systems are designed for the optimal use of fuel input, converting as much as (90\% to $96 \%$ ) of the fuel into usable energy through production of both electricity and heat. Such increased efficiency of CHP systems result in lower fuel consumption, which provides an equivalent reduction of emissions thus reducing the environmental impact $[2,3]$.

CHP systems are also flexible in view of fuel used; natural gas is the ideal and cleanest burning alternative fuel, but a number of alternative fuels can be used, such as biogas, biodiesel, low-sulphur diesel, etc.

\section{COMBINED HEAT AND POWER VERSUS SEPARATE GENERATION}

Figure (3) is used as a basis to illustrate the fundamental differences between CHP and separate conventional distributed generation, which are depicted in Table (2), extracted and modified from $[4,5]$. 
Table (2): Fundamental Differences between CHP and Separate Conventional Distributed Generation

\begin{tabular}{|c|c|}
\hline Separate Generation & CHP Units \\
\hline $\begin{array}{l}\text { Two systems, one produces electrical } \\
\text { energy and the other produces heat } \\
\text { energy }\end{array}$ & $\begin{array}{l}\text { Only one system producing electricity and } \\
\text { heat at the same time }\end{array}$ \\
\hline $\begin{array}{l}\text { Uses primary fossil fuels with higher } \\
\text { emissions }\end{array}$ & $\begin{array}{l}\text { Uses various types of clean fuels (natural } \\
\text { gas, liquefied petroleum gas, biogas and } \\
\text { other types) }\end{array}$ \\
\hline $\begin{array}{l}\text { Inefficient, only converting an average } \\
\text { about a third of fuel into usable energy }\end{array}$ & $\begin{array}{l}\text { Efficient, converting as much as ( } 85 \% \text { up } \\
\text { to } 96 \% \text { ) of fuel into usable energy }\end{array}$ \\
\hline High maintenance requirements & Less maintenance requirements \\
\hline High noise & $\begin{array}{l}\text { Smallest noise because compact } \\
\text { construction }\end{array}$ \\
\hline High area requirement & $\begin{array}{l}\text { Less area requirement, usually located } \\
\text { near the end user }\end{array}$ \\
\hline $\begin{array}{l}\text { Lower initial investment cost as } \\
\text { compared to CHP system }\end{array}$ & $\begin{array}{l}\text { Higher initial investment cost as compared } \\
\text { to separate system (but life cycle benefits, } \\
\text { shorter payback periods) }\end{array}$ \\
\hline
\end{tabular}

\section{Conventional}

Generation

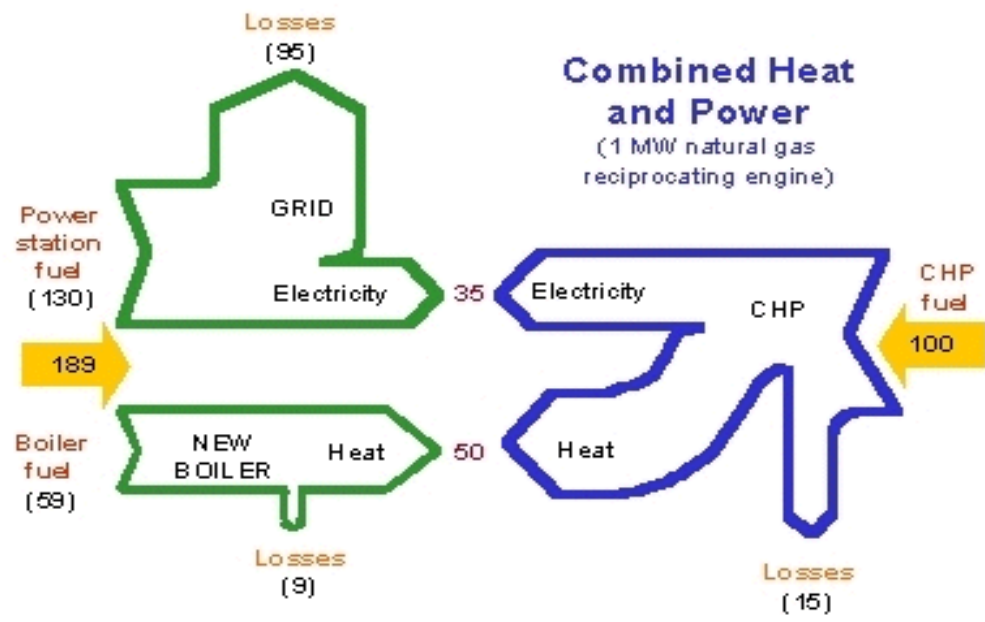

Figure (3): CHP Versus Separate Conventional Distributed Generation [6]

The above comparison reveals the following advantages of introducing CHP units to cover electrical and thermal demand at industrial plants: 
- Economic Advantages:

- Reduction of overall energy expenditures due to improved overall fuel efficiency

- Resale of excess power to public power supply

- Reduction of O\&M costs

- Fuel preservation

- Environmental Advantages

o Less emissions per delivered unit of output

o Overall reduction of emissions due to fuel preservation

- Technical Advantages

o Less dependence of industrial facility on public power supply

o Improved reliability and power quality

\section{TECHNICAL AND ECONOMIC FEASIBILITY}

Like any other project, a project for introducing CHP requires performing prefeasibility studies and final technical and economic feasibility studies, site by site due to the nature of simultaneous generation of electrical and thermal energy. A candidate site not suitable for CHP introduction can be avoided early from the very beginning as a result of a very short pre-feasibility study.

\section{- Technical Feasibility}

This includes the survey of the candidate site to collect energy demand data, including electrical and thermal demand profiles, duration, load factor, annual operating hours, fuels available, ... etc. to identify the different technical options and develop preliminary system designs.

\section{- Economical Feasibility}

For each option proved to be technically feasible, extensive economic analysis should be performed to identify economic feasibility, in terms of payback period, net present value and internal rate of return, taking into consideration the initial investment (fixed costs), O\&M costs (moving costs), fuel prices and energy purchase and resale tariffs.

\section{POLICY FRAMEWORK FOR PROMOTING CHP INTRODUCTION}

There are a lot of policies in Yemen that encourage efficient energy production and environment-friendly technologies.

- The third five-year development plan (2006-2010) emphasizes natural gas utilization as substitute for other energy resources. A strategy for utilization of natural gas in the different economic activities will be prepared. One of the strategic projects of this plan is finalizing the studies and execution of the planed domestic gas pipeline (Mareb - Ma'abar - Hodeida - Aden) to utilize natural gas for power generation, strategic industries and transport means, ... etc. [7].

- The amended Environment Law, 2006 [8] speaks in its Article (12) for supporting pilot projects for transfer and adoption of environment-friendly technologies, including clean energy production and extension in natural gas applications and 
clean industry techniques to alleviate industrial emissions, waste recycling and cleaner production technology. Article (15) imposes industrial pollution fee amounting to $1 \%$ of the value of all imported diesel engines, including vehicles diesel engines to be paid to the customs authority. In addition, Article (37) contains regulations for pollution control in industry, power generation, constructions or any other commercial purpose. The Articles $(70,71)$ deal with pollution monitoring schemes at licensed projects and environmental records.

- CHP is identified in Yemen's First National Communication [9] as one of the mitigation options on supply- as well as on demand side, along with fuel-switching to LNG, CNG and LPG in addition to 'rational' use of energy.

- Independent Power Producers (IPP) are encouraged to invest; power purchase and resale agreements have been established. Recently, leasing financing is also introduced in Yemen [10].

Despite of above, and in the absence of a national energy efficiency program, CHP is not yet introduced in Yemen, not only into industry but also into other economic sectors. The barriers existing in Yemen to introducing CHP can be classified into the following:

Technical Barriers:

- Unfamiliarity with CHP due to lack of technical information among planners, manufacturers, utilities, chambers of commerce \& industry, ... etc.

- Shortage in technical expertise to design, construct and operate CHP systems

- Lack of domestic natural gas infrastructure so far

Market Barriers:

- The market is unaware of technology developments that have expanded the potential for CHP

- Diesel and electricity subsidies for conventional sources of energy

Economic and Financial:

- The relative high investment cost (though life cycle benefits, reasonable payback period)

- Lack of financial institutions (Lease financing legislative framework recently approved)

- No encouragement for power resale to public grid

Institutional Barriers:

- Lack of institutions or inadequate institutions to deal with energy and environment matters

- Lack of national commitment of national authorities to promote CHP to conserve fossil fuels and protect the environment

- Absence of national energy efficiency improvement programs to make conservation campaigns and disseminate information on energy efficient technologies, including CHP 


\section{PRACTICAL APPROACH TO GRADUAL CHP INTRODUCTION}

Introduction of CHP implies overcoming the main barriers mentioned above. In parallel to that, awareness building about CHP and cogeneration is the very first step. Capacity building measures are also badly needed.

Table (3) summarizes the practical steps towards introducing CHP into the industrial sector in Yemen. Any step of them represents a progress forward, which should be appreciated.

Table (3): Practical Steps towards Introducing CHP into the Industrial Sector in Yemen

\begin{tabular}{|c|c|c|}
\hline Step & Features & Remarks/Images [11] \\
\hline $\begin{array}{l}\text { CHP Pilot Projects } \\
\text { (Demonstration of } \\
\text { CHP features at ideal } \\
\text { candidate sites) }\end{array}$ & $\begin{array}{l}\text { - First experience to users } \\
\text { - Performance tracking enabling } \\
\text { comparison with separate } \\
\text { generation of heat and power } \\
\text { - Demonstration of CHP benefits } \\
\text { - Provides market leadership }\end{array}$ & \\
\hline $\begin{array}{l}\text { Exhaust Gas Heat } \\
\text { Recovery } \\
\text { (To substitute part of } \\
\text { boilers capacity, or } \\
\text { replace aged boilers) }\end{array}$ & $\begin{array}{l}\text { - Recovery of } 10-30 \% \text { of input } \\
\text { fuel energy } \\
\text { - Intermediate boilers or heat } \\
\text { exchangers on exhaust gases } \\
\text { runway } \\
\text { - Used for water heating and/or } \\
\text { low pressure steam production }\end{array}$ & \\
\hline $\begin{array}{l}\text { Conversion of } \\
\text { Existing Separate } \\
\text { Generation Schemes } \\
\text { into Fully } \\
\text { Functioning CHP } \\
\text { Units }\end{array}$ & $\begin{array}{l}\text { - Full utilization of CHP benefits } \\
\text { - Reduction of boilers capacity } \\
\text { - Alternative solution to boilers } \\
\text { replacement }\end{array}$ & \\
\hline $\begin{array}{l}\text { CHP Units Standard } \\
\text { to Meet Simultaneous } \\
\text { Thermal and Power } \\
\text { Demand } \\
\text { (Where best suited) }\end{array}$ & $\begin{array}{l}\text { - Above steps will contribute into } \\
\text { convincing planners and } \\
\text { manufacturers with CHP } \\
\text { features } \\
\text { - New projects, planned } \\
\text { industrial zones, future projects } \\
\text { adopt CHP where technically } \\
\text { and economically feasible }\end{array}$ & $\underset{\text { cogenco }}{0}$ \\
\hline
\end{tabular}




\section{CONCLUSION}

A brief introduction to combined heat and power generation, along with its advantages is given in this paper to encourage its introduction to industrial plants in Yemen to meet their heat and power demands with a very high overall fuel efficiency. The existing barriers are discussed and a practical approach to gradual combined heat and power introduction is proposed.

\section{REFERENCES}

1. Guidebook on Cogeneration as a means of Pollution Control and Energy Efficiency in Asia. Economic and social commission for Asia and the Pacific, United Nations, 2000

2. www.chp.bre.co.uk/chptypes.htm

3. www.turbec.com/energy/the-microturbine.htm

4. www.aph.gov.au/index.htm

5. www.eren.doe.gov/der/chp/index.htm

6. CHP Basics, United States Combined Heat and Power Association, http://uschpa.admgt.com/CHPbasics.html

7. Yemen's Third Five-Year Development Plan (2006-2010), Ministry of Planning \& International Cooperation, www.mpic-yemen.org

8. Yemen's Amended Environment Law 2006, Environment Protection Authority (EPA), 2006, www.yemen-environment.org

9. Yemen's First National Communication, 2001, Environment Protection Authority (EPA), 2006, www.yemen-environment.org

10. Leasing Financing Law, 2007

11. Sources of Images (Table 3):

1) CHP with micro-turbine as prime mover, from $30 \mathrm{kWe}$ to $500 \mathrm{kWe}$ http://www.bgtechnology.com/eneryvortal.nsf/

2) 6 Nos. Exhaust Gas Boilers (EGBs) behind Wartsila Diesel Engines, generating $20 \mathrm{t} / \mathrm{h}$ steam for process use www.me-engineering.co.uk/ProductShowcase.htm

3) www.enercon-eng.com

4) www.cogenco.co.uk 
الوحدات المدمجة لتوليد الطاقة الحرارية والكهريائية واستخد/مها في القطاع الصناعي في اليمن للحصول على كفاعة أعلى لاستخدام الوقود

تعتمد معظم المصانع في اليمن على التوليد الذاتي للطاقة الكهربائية لتغطية احتياجاتها وهو

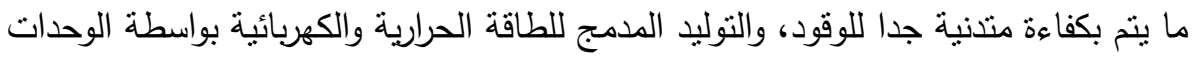

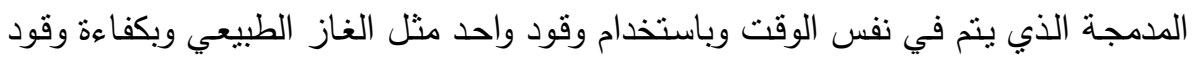
إجمالية تتجاوز 80\% لا يزال غير مستخدم ولا معروف.

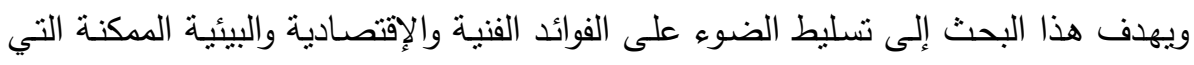
ستتجم عن إدخال هذه الوحدات في القطاع الصناعي، كما يناقش المعوقات التي تحول دون

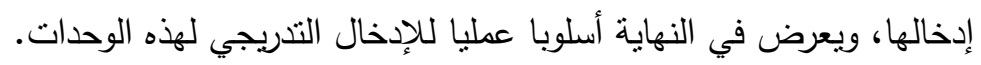

